\title{
ULUSLARARASI HUKUKTA İNSANLIĞA KARŞI SUÇLAR
}

Dr. Ezeli AZARKAN*

\section{A- GIRISS}

İnsanlığa karşı suçlar kavramı, II. Dünya Savaşı sonrası uluslararası hukuk metinlerinde yer almaya başlamış, dinamik bir kavramdır. Ulusal ve uluslararası alanda yaşanan gelişmeler, bu kavramın içeriğinin giderek daha belirginleşmesine ve ortak bir tanıma ulaşma yönünde ilerlemelerin sağlanmasına katkıda bulunmuştur.

İnsanlığa karşı suçlar kavramı, devletin insanlara yönelik giriştiği insanlık dışı eylemlerine atıf yapılarak belirtilen bir kavram niteliği taşımıştır. Birleşmiş Milletler (BM) Şartı’nın ilanına kadar bu kavram, devletlerin kendi azınlıklarına karşı yürüttüğü insanlık dışı faaliyetleri ifade etmek için kullanılmıştır. Söz konusu kavramın, devletin savaş sırasındaki eylemleri için kullanımı ise "La Haye Sözleşmeleri"yle gerçekleşmiştir'.

I. Dünya Savaşından sonra, bireyleri, cezaî sorumluluk kapsamında insanlığa karşı suçlardan dolayı yargılama girişimleri başlamış; ancak bu girişimler, 1I. Dünya Savaşına kadar bir sonuç vermemiştir. İnsanlığa karşı suçlar, II. Dünya Savaşı sonrası Müttefikler tarafından kabul edilen Nuremberg Mahkemesi Statüsünde, mahkemenin yargılama kapsamı içine aldığı üç suç tipinden birisi olmuştur.

* Dicle Üniversitesi Hukuk Fakültesi Araştırma Görevlisi.

' RATHER, Steven R,Jason, Abrahams: Accountability For Human Rights, Atrocities in Intemational Law, Oxford, Clarendon Press, 1997, s.45. 
Nuremberg Mahkemesi Statüsünuin 6/c maddesinde, insanlı̆̆a karşı suçlar: "savaş süresince veya savaşıan önce öldürme, imha, köleleştirme, sürgün ve sivil insanlara karşı girişilen diğer insanlık dışı muameleler veya mahkemenin yargı kapsamına giren suçlarla ilintili dimi, siyasi ya da ırksal nedenlerden dolayı yargılanma"-- diye tanmlanmaktadır.

$\mathrm{Bu}$ şekilde tanımlanan insanlığa karşı suç kavramını daha iyi anlayabilmek için, her şeyden önce söz konusu kavramın tarihsel süreç içerisinde geçirdiği evrimi bilmek gerekir. Bu nedenle, çalışmamızda öncelikle bu kavramın geçirdiği evrimi, daha sonra ise, uluslararası belgelerdeki düzenlenişini incelemeye çalışacağız.

\section{B-1945'TEN ÖNCE KAVRAMIN GELIŞIMI}

İnsanlığa karşı suçlar kavramının ortak bir kullanışa sahip olduğunu söylemek güçtür. Bu terim ilk olarak 28 Mayıs 1915'te Ingiltere, Fransa ve Rusya'nın, Türkiye'deki Ermenilerin katledildikleri iddiasıyla yayınlamış oldukları deklarasyonda yer almıştır". Bu deklarasyonda, "insanlığa karş̧ suçlar"ın savaş suçlarından ayrı olarak ele alınması gerektiğ̣ine ilişkin öneriler devletlerin itirazlarıyla karşılaşmıştır. Bu karşı çıkışın temel dayanağımı, 1907 tarihli kara savaşı hukuk ve teamüllerine ilişkin "La Haye IV. Sözleşmesi” oluşturmuştur ${ }^{4}$. Bu Sözleşme, aynı zamanda, insanlığa karşı suç kavraınının çkışş noktasını teşkil etmiştirs".

? Bu hüküm hakkında bkz. CLARK. Roger S. "Crimes Aganist Humanity at Nuremberg". Nuremberg Trial and International Law. Ed. George GiNSBURGS. W.N. KUDRIA VTSEV . Dordrecht.Martinus Nijhoff Publishers . 1990, s.177.

" DRAPER.G.1.A.D. : "The Modern Pattern of War Criminality". War Crimes in International Law, Ed. Yoram DINSTEIN - Mala TABORY. The Hague. Martinus Nijhofr Publishers.1996, s.149-150; ASKIN, Kelly. D., War Crimes Aganst Women. The Hague,Martinus Nijhofi Publishers, 1997, s.140; ROBERGE. Maric- Clatule. "Iurisdection of ad hoc Tribunals for The Fonner Yugoslavia and R wanda over Crimes Against Humiurity and Genocide". IRRC. No.321., s.655.

"CLARK. Roger S. :"Crimes Aganist Humanity at Nuremberg", Nuremberg Trial and International Law. Ed.George GINSBURGS. W.N. KUDRIAVTSEV, Dordrecht, Martinus Nijhoff Publishets , 1990 .s.178.

${ }^{5}$ ASKIN, War Crimes...s. I40; ROBERGE, a.g.m., .655. IV. La Haye Sözeșmesinin önsözünde. Sozleşmeyc taraf olanların uluslararası hukuk, uygar insankar utasıkda oluşturulan ilkeler, insâtcil hukuk ilkeleri ve kamı vicdanı gözetilmesiyle ortaya çıtharlan ilkeler

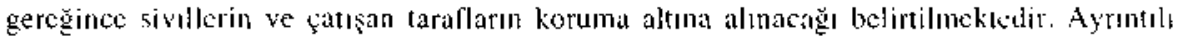
bilgi için bk\% GREENSPAN, Moris. The Modern Law of Land Warfarc. Californit. University of California Press, 1959, s.437 vo..; COTLER. Irwin, "Reginá v. Finta i 1694) । s.c.r. 701. Supreme Court of Canada March 24.1994". AJIL. Vol.90, No.3.1996, ...465. 
I. Dünya Savaşı sonrasında barış konferansına hazırlık komisyonunun azınlıklarla ilgili hazırlamış olduğu bir raporda, ceza yargılamasının, "savaş hukuku ve teamüllerinin veya insancıl hukukun ağtr ihlalleri"nden dolayı yapılacağı belirtilmişsir ${ }^{6}$. Burada savaş hukuku ve teamüllerinin ihlalleri ile insancıl hukuk ayrı ayrı zikredilmiştir. Ancak, komisyonun bu ifadesi barış antlaşmalarında yer almamıştır ${ }^{7}$.

Bu sorun, 1940 'larda BM savaş suçları komisyonu ile ilgili tartışmalara ve Nuremberg Mahkemesi Statü Taslağının hazırlandığı Londra Konferansına kadar kaldı. BM Savaş Suçları Komisyonu, 20 Ekim 1943 tarihinde toplanan diplomatik konferansın aldığı kararla kuruldu ${ }^{8}$. Komisyon, II.Dünya Savaşı süresince işgal bölgelerinde siyasi, dini ve ırksal nedenlerden ötürü yapılan ihlallere ilişkin çalışmalar yaptı. Bu çalışmalar. insanlığa karşı suçları da içeren Nuremberg Şartının oluşumuna katkıda bulundu.

Nuremberg Uluslararası Askeri Ceza Mahkemesi Statüsünün ele alındığ Londra Konferansı, 26 Haziran-8 Ağustos 1945 tarihleri arasında toplandı. Konferans öncesi hazırlanan ilk taslaklarda insanlığa karşı suçlar kavramından söz edilmiyordu'. Konferans süresince gerek ABD gerekse diger muittefik devletlerin sundukları taslaklarda insan hakları ihlallerine değinilmekle birlikte, bağımsız bir başlık altında insanlığa karşı suçlar ele alınmadı. Son olarak, 30 Temmuz 1945 tarihinde ABD tarafından hazırlanan ve insanlığa karşı suçların bağımsız bir başiık altında toplandığ bir taslak, konferansa sunuldu.

Konferansta son şekli verilerek kabul edilen Nuremberg Statüsü ve Nuremberg Mahkemesinde yapilan yargilanmalar, uluslararası hukuk çerçevesinde insanlığa karşı suçu temel bir kavram olarak ele almıştır. Ayrıca, Mahkeme Statüsü, ilk kez insanlığa karşı suçların tanımının yapıldığı bir uluslararası hukuk belgesi olma özeliğine sahiptir ${ }^{10}$.

Nuremberg Mahkemesinde insanlığa karşı suçlar iki kategoride ele alınmıştır. Birincisi, sivil nüfusa yönelik yapılan suç teşkil edici eylemlerdir.

(6) RATHER-ABRAMS,a.g.c.s.45; BElGBEDER. Yves: Judging War Criminals. London. Macmilan Press and St. Martin Press, 1999.s.27-28; ROBERGE.a.g.m..s.652. Komisyonun ayrıntılı çalışmaları için bkz. SANDOZ, Yves: "Penal Aspects of International Humanitarian Láw". War Crimes and International Tribunals. Ed. Gabrielle Kirk MCDONALD . Geneva, ICRC-Graduate Institute, 1998, s.226 vd.

${ }^{7}$ RATHER-ABRAMS,a.g.e., s.46.

${ }^{8}$ SANDOZ, Penal Aspects...,s.219.

${ }^{9}$ CLARK,a.g.m.s. 181.

ItWAGNER, J. Martin," Prosecution of War Criminals", Virginia Journal of International Law. Vol.29,1989,s.906. 
İkincisi de, siyasi, ırkçı ve dini nedenlerden dolayı yargılamalardır" ${ }^{\prime \prime}$. Benzer ayrım, "Uzakdoğu İçin Uluslararası Ceza Mahkemesi"nde de yapılmıştır. Diğer yandan, bunlar, insanlığa karşı suçlar ile savaş suçları arasında belirgin bir ayrımın ne olması gerektiği konusunu çözüme kavuşturmamışlardır. Bu muğlaklık, Nuremberg Mahkemelerinin yargı sınırlarımın çizilmesinde doğan güçlüklerde kendini bariz bir şekilde hissettirmiştil. Özelikle, Eylül 1939'dan önce Nazilerce işlenmiş suçların araştırılmasında, Mahkemenin yargı yetkisinin smırı, suçların Il. Dünya Savaşıyla doğrudan ilintilendirilmesi konusunda derin bir incelme yapilmasıma engel olmuştur'?

Kanımca, insanlığa karşı suçlar doktrininin oluşumuna katkı sunan bir çok öğe, doktrininin kendisinden değil, fakat, uluslararası kamuoyunun i]gilendiği diğer suçlardaki birbirini izleyen gelişmelerden beslenmektedir. Orneğin, saldırgan savaş suçunun oluşumuna ve savaş suçlarının tekrarlanmasımın insanlığa karşi suçun ortaya çıkmasına etki etmesinde olduğu gibi. Benzer şekilde, soykırım ve ırk ayrımı suçunun tanımlanması ve uluslararası suçlarda meydana gelen gelişmeler, insanlığa karşı suç kavramına doğrudan etkide bulunmuştur.

\section{C - ULUSLARARASI HUKUKTA INSANLIĞA KARŞI SUÇLARA ILISSKIN GELISSMELER}

Uzun zamanơan beri, sivillere karşı insanlık dışı muameleler ulusal hukuk kapsamında yargllanmaktaydı. Bazı durumlarda, uluslararası hukuk kuralları (uçak kaçırma, köle ticaretine ilişkin kurallar vb.), uluslararası toplumu rahatsız eden hukuk dışı eylemler ve evrensel etik değerlerin ihjallerinden ötürü bireylere yönelik bir takım cezalandırıcı hükümler içerir. Insanlığa karşı suçların bu suçlardan ayırt edici özelliği, insan haklarım geniş ve büyük ölçüde ihlalinin, uluslararası barış ve güvenliği tehdit edici ve uluslararası suçları teşvik edici bir niteliğe sahip olmasıdır ${ }^{13}$.

II. Dünya Savaşı sonrasında uluslararası toplum, uluslararası suçları önleme yönündeki kesin tavrını insan hakları kavramına saygı çerçevesinde sadece ulusal hukuk duizeyinde değil, uluslararası hukuk kapsamında da kesin hükümlere bağlama yönünde yoğun çaba göstermiştir. Bu paralelde, insan haklarmı koruyan ve garanti altma alan ve bunlara devletlerin saygı göstermesini săğlayan uluslararası hukuk kurallarına ek olarak, birçok

"LEPPER, Steven. Remarks, ASIL Proccedings. 7 Nisan 1994, s.242.

1: CLARK.a.s.m...s.198.

1: RESHETOV, Iu.A., "Development of Norms of lntemational Law on Crimes Against Humanity", The Nuremberg Trial and International Law,Ed. George GINSBURGS and V.N. KUDRIAVTSEV. Dordrecht, Martinus Nijholf Publishers , 1990,s.199. 
uluslararası sözleşme, insanlığa karşı suçları önleme ve insan haklarını korumaya ilişkin somut kuralları ayrıntılı bir şekilde diizenlemiştir.

Yukarda belirttiğimiz insanlığa karşı suçlara ilişkin ayırt edici özelikler dışında bir takım başka özellikler de mevcuttur. Bunlar, savaş veya barış zamanında sivillere karşı girişilen sürgün, köleleştirme, imha, öldürme ve bunlara benzer insanlık dışı muameleleri içermeleridir ${ }^{14}$.

BM bünyesindeki Uluslararası Hukuk Komisyon (UHK)'nun insan güvenlik ve barışına karşı suçlara ilişkin kuralları içeren taslak raporunda, insanlığa karşı suçlar şu şekilde sıralanmıştır: Devlet veya özel kişilerce veya bunların teşvikiyle sivillere karşı girişilen öldürme, imha, köleleştirme, sürgün veya acı çektirme suçları ${ }^{15}$.

II. Dünya Savaşı sonrası dönemde insanlığa karşı suçları önlemek için fazla sayıda çok taraflı sözleşmeler imzalanmıştır. Bu sözleşmelerin ortak noktası, uluslararası hukukta insanlığa karşı suçlara ilişkin birey sorumluluğunu belirtmeleridir ${ }^{16}$. $\mathrm{Bu}$ sorumluluktan dolay1 bireylerin yargılanması, ulusal mahkemelerin yanı sıra -uluslararası cezaî sorumluluk çerçevesinde- uluslararası ceza mahkemelerinde de söz konusu olabilmektedir. Uluslararası hukuk uyarınca, resmi devlet görevlileri bu suçlardan dolayı cezaî sorumluluğun đışında bırakılmamış; gerek kişisel gerekse devlet sorumluluğu bağlamında işlenilen suçlardan dolayı sorumlulukları kabul edilmiştir.

İnsan haklarına saygıyı teşvik eden ve geliştiren BM Şartı ve "Tüm Irk Ayrımcılığı Çeşitlerini Ortadan Kaldırılmasına Illişkin Uluslararası Sözleşme" gibi bazı uluslararası belgeler, insanlığa karşı suçlar içeren uluslararası sözleşmeler için başvuru kaynağı olmuştur. Bunların yanı sıra, insanlığa karşı suçlara ilişkin uluslararası belgelerin başlıcaları şunlardır: 1948 tarihli Soykırım Suçunun Önlenmesine ve Cezalandırılmasına Illişkin Sözleşme, 1973 tarihli Irk Ayrımının Önlenmesi ve Cezalandırılmasına Ilişkin Uluslararası Sözleşme, 1968 tarihli Savaş Suçları ve İnsanlığa Karşı Suçların Sınırlanmasına İlişkin Sözleşme, 1974 tarihli Insanlığa Karşı Suçlar ve Savaş Suçlarının Sınırlanmasına İlişkin Avrupa Sözleşmesi ve 1984 BM İşkence Sözleşmesidir. Burada önemi açısından ilk iki sözleşmeyi inceleyeceğiz.

\footnotetext{
${ }^{1+}$ Ibid,s.199-200.

${ }^{15}$ ROBERGE.a.g.m.,s.655 : ALSAN, Mesut Zeki, "Bir Milietlerarası Ceza Divanı Kurulmasıyla ilgili Fikirler ve Teşebbüsler". AÜHF Dergisi. C. VIII sayı.3-4. 1951,s.13-15.

${ }^{16}$ RESHETOV a.g.m., s.200.
} 
Soykım, BM Genel Kurulunun 11 Kasım 1946 tarihinde aldığı kararla uluslararası suç sayılmıştır ${ }^{17}$. Yine, BM Genel Kurulunun 21 Aralık 1947 tarihli 180/1 sayılı kararıyla "soykırımın. kişi ve devletlerin ulusal ve uluslararası sorumluluğunu gerektiren uluslararası bir suç olduğu" kabul edilmiştir.

1948 Soykırım Suçunun Önlenmesi ve Cezalandırılmasına İlişkin Sözleşmenin 1. maddesi "soykırımın, uluslararası hukuk kapsamında barış veya savaş zamanında işlenen bir suç oldugünu belirtmiş ve taraf devletleri bu suçun "önlenmesi ve cezalandırılması" için yükümlülük altına sokmuştur $^{l .}$. Yine, Sözleşmenin 2. Maddesi, soykurım sayılacak eylemleri belirtmiştir. Bu maddede soykırım; ulusal, etnik, trksal veya dini grupların bütünü veya bir kısmının kasti olarak yok edilmesi şeklinde tanımlannıştıิ ${ }^{19}$. Böylece soykırım sadece bir ihlal olarak değil, aynı zamanda insan haklarının geniş ölçüde ortadan kaldırılması olarak kabul edilmiştir. Burada dikkat edilecek nokta, bir gruba mensup bir kişinin öldürülmesi eyleminin soykırım eylemi oluşturup oluşturmadığı sorunudur. Böyle bir durumda önem kazanan husus, failin niyetidir. Eğer yapılan eylem bir grubun yok edilmesi amacına yönelik bir planm parçası ise veya böyle bir niyet taşıyorsa, eylem soykırım niteliği taşır; aksi takdirde, bu eylem bir zulämdür, soykırım değildir.

Sözleşmenin 4. maddesi soykırım suçu işleyen kişi ve hükümet yetkililerinin uluslararası sorumluluğunu teyit etmiştir. Sözleşmenin 6 . maddesi ise, bir yandan soykırım suçunun işlendiği ülkenin ulusal mahkemelerine sanığı yargılama yetkisi tanırken, diğer yandan soykırım davasının bir ulustararası ceza mahkemesinde görülmesi halinde. Sözleşmeye taraf devletlerin, dava yetkilerini uluslararası mahkemeye devredilebileceğini belirtmiştir ${ }^{20}$.

Soykırım ve benzeri uluslararası suçlarla muicadele etmek, uluslararası hukuk bakımından soykırım sözleşmesine taraf olan ve olmayan tüm devletler için bir zorunluluğa işaret etmektedir. Bu bakimdan, bazı

${ }^{17}$ SHAW. M.N., "Genocide and International Law". International law at A Time of Perplexity Essays in Honour of Shabtai Rosenne, Ed. Yoram DiNSTEIN. Dordrecht. Martinus Nijhoff Publishers. 1989.s.799.

${ }^{1 \times}$ RATHER-ABRAMS,a.g.m.s.26: WYNGAERT,a.g.e.s.35.

"HANNUM. Hurst. "International Law and Cambodian Genocide: The Sounds of Silence“. Human Rights Quarterly, Vol.II No.1,1989.5.86. RATHER-ABRAMS.atg.e.s.27; WYNGAERT. Christinc Van Den.GUY. Slessens: Intemational Criminal Latw, The Hague. Kluwer Law International, $1996, \$ .35$.

It SHAW, Genocide ..., s.815-816; HANNUM, a.g.m., s.94; WYNDAERT-GUY, a.g.c. s. 36. 
devletlerin soykırım sözleşmesine taraf olmaması, bu devletlerin kendi vatandaşlarına soykırım yapma hakkına sahip olduğu anlamına gelmez ${ }^{21}$.

İnsanlığa karşı suçlar ile doğrudan ilgili bir diğer uluslararası belge, "Irk Ayırımının Önlenmesi ve Cezalandırılmasına İlişkin Uluslararası Sözleşme"dir. Sözleșme, BM Genel Kurulunca 30 Kasım 1973 tarihinde kabul edilmiş ve 18 Temmuz 1976 tarihinde yürürlüğe girmiştir ${ }^{22}$. Sözleşme, uluslararası ceza hukukunun kodifikasyonuna ve gelişmesine önemli katkılarda bulunmuş: ırk ayırımı gibi uluslararası suçlarla mücadeIe için gerekli kuralların oluşumuna kaynaklık etmiştir.

BM, ırk ayırımcılığına karşı yürütülen çalışmalara destek vermekte ve bir çok kararlarında bunun insanlık dışı bir eylem olduğunu belirtmektedir. BM Güvenlik Konseyi, $1990^{\circ}$ lı yılların başına kadar, Güney Afrika yönetiminin ırk ayrımcılığı politikası ve uygulamalarının uluslararası barış ve güvenliği tehdit ettiğini defalarca ilan etmiştir.1980'li yıllarm sonuna kadar, Güney Afrika yönetimi şu eylemleri sistematik bir şekilde uygulamıştır: Afrikalıları öldürme ve imha etme, köleleștirme, ırk ayrımı ve sivil halka yönelik diğer insanlık dışı muamelelerde bulunma ${ }^{23}$.

Irk Ayırımı Sözleşmesinin 1.maddesi. "ırk ayırımının insanlı̌̆a karş1 işlenmiş bir suç olduğunu" belirtmektedir. Sözleşmenin 2. maddesinde tanımlanan trk ayrımı politikaları ve uygulamaları sonucu meydana gelen insanlık dışı eylemler, uluslararası hukuku ihlal eden suçlar olup, BM Şartını ihlal ve uluslararası barış ve güvenliği ağır şekilde tehdit eden bir niteliğe sahiptir. Sözleşmeye taraf devletler, ırk ayrımı suçu işleyen kişilerin, örgütlerin ve kurumların suçluluğuna ilan $\operatorname{ede}^{24}$. Bu çerçevede, bu maddede altı çizilen unsur, politika ve uygulamalara göre belirtilen ırk ayrımı suçunun tanımıdır. Böylelikle, ırk ayrımını ifade eden gerekli koşullar sadece zorunlu çalıştırma ve öldürme gibi eylemlerle sınırlı kalmamakta; aynı zamanda, 1rkçıllı temeline dayanan sistematik bastırma ve boyunduruk altına alma ögelerini taşıyan ayırımcılık politikası oluşturan yasama işlemleri de bu kapsam dahilinde değerlendirilmektedir.

Sözleşmenin 2. maddesi 1. maddeyi teyit ederek, ırk ayırımı suçunun kaçınılmaz şartının, bunun amaçlanmasına yönelik bir niyetin olduğunu belirtmektedir. Bu madde, "bir ırk üyesinin başka ark grubu üyelerinden üstün tutulması, bir ırka ayrıcalık tanınması ve sistematik olarak diğerlerine

\footnotetext{
21 SHAW, Genocide...,s.796; HANNUM,a.g.m.s.95-96.

2 RATHER-ABRAMS ,a.g.e.,s.1 13.

${ }^{27}$ RESHETKOV,a.g.m., 205.

${ }^{24}$ WYNDAERT - GUY,a.g.e.s.37-38.
} 
baskı yapılması" eylemlerinin, ırk ayrımcılığı esasına dayalı bir insanlık dışı muamele oluşturduğunu vurgulamaktadır.

Sözleşmenin 4. maddesi ise, Sözleşmeye taraf devletleri ırk ayrımı suçunun önlenmesi için gerekli tedbirlerin alınması konusunda yükümlülük altına sokmuştur.Sözleşme, taraf devletlere bu suçu işleyen kişinin uyruğuna bakılmaksızın yargılanması ve cezalandırılması yetkisini tanımışıı.

Soykirım Sözleşmesinin yargyya ilişkin temel ilkesi, suçun işlendiğ̣i yer (ïlke) mahkemelerinin sanıkları yargılama yetkisine sahip olduğu yönündedir. Irk Ayırımı Sözleşmesi ise bundan farklılık arz etmektedir. 1990 yılına kadar Güney Afrika'da ırk ayırımcılığı suç değildi. Bu eylemleri yapan kişiler herhangi bir yaptırım ile karşılaşmıyordu. Sözleşme, taraf devletlere, kendi sınırlan dışında da bu suçu işleyen kişileri kendi ulusạ mahkemelerinde yargılama yetkisi vermiştir. Diğer yandan, Sözleşme, irk ayrımı suçunu yargılayan uluslararası bir mahkemenin bulunması halinde, taraf devletlerin bu mahkemenin yargı yetkisini kabul edeceğini belirtmektedir.

Irk Ayırımı Sözleşmesi, ırk ayrımı konusunda, kişilerin uluslararasıı suçlardan dolayı bireysel cezaî sorumluluğunu teyit etmiş ve geliştirmiştir. Bu bağlamda, bu sorumluluğun özelliği, suçun özel bir sosyal tehlike oluşturmasııdır.

Uluslararası Hukuk Komisyonu’nun devlet sorumluluğuna ilişkin hazırladığı taslağa ilişkin yaplan tartışmalar sırasında, soykırım ve ırk ayrımı gibi uluslararası suçların BM Şartının IV. Bölümü çerçevesinde ele alınması gere ği dile getirilmiş: uluslararası barış ve güvenliğ̣in bu suçlar nedeniyle tehlikeye girmesi halinde BM'nin önlem alma gereği belirtilmiştir.

İnsan hakları ihlallerinden kaynaklanan devlet sorumluluğu, bu gibi ihlallerin önlenmesine yönelik yasal düzenlemelerin yapılmaması veya var olan düzenlemelerin uygulanmamasından ortaya çıkmaktadır. Ayrıca bu sorumluluk, devletin siyasal yapısından ve kurumlarının uygulamalarından da kaynaklanmaktadır ${ }^{25}$. Devletin bazı yetkililerin ırk ayrımı niteliğindeki faaliyetlerde bulunmaları, devletin resmi kurumlarının bu suça yaklaşımından kaynaklanabilmektedir. UHK, devlet sorumluğuna ilişkin taslağın 27. Maddesinde, devletin yardım ve teşvikiyle yapılan uluslararası haksız eylemler ve devletin doğrudan kendisinin işlediği ulustararası hakisız eylemlerin devlet sorumluluğunu gerektirdiğini belirtmektedir.

\footnotetext{
${ }^{*}$ RESHETOV, a.g.m.s. 209 .
} 
Irk ayrımı politika ve pratiği, bir devletin ulusal sınırları içinde yaşayan başka renkten insanlara karşı idari uygulamalardan oluşmaktadır. Irk ayrımı durumu, bazı öğelerin varlığıyla söz konusu olmaktadır. Bu öğelerden birincisi, insanlara karşı girişilen baskıcı eylemlerdir. Bu eylemler; bir ırka mensup üyelerin yaşam hakkından yoksun bırakılması, fiziksel yıkıma neden olacak koşullar içinde tutulması, gelişmelerinin önlenmesi ve zorunlu olarak çalışiırılması. Bütün bunlar, ırk ayırımını oluşturan ögelerdirr ${ }^{26}$. Öğelerden ikincisi, hukuk kurallarına ve evrensel ahlâk ilkelerine uyulmamasıdır. Diğer bir deyişle, insanların kişiliklerinin ve yaşamsal değerleriyle eşitlik ve özgürlüklerinin çiğnenmesidir. Irk ayrımı politika ve uygulamaları evrensel etik değerlerle bağdaşmaz. Bunlar, söz konusu değerleri tehdit eden başlıca unsurlardır. Aynca bunlar, uluslararası düzeni de tehdit etmektedir.Üçüncü öğe ise, siyasi durumdur. Bu öğe, daha çok iki öğenin oluşmasına katkıda bulunan ve onların etki ve derecesini belirleyen bir öğedir.

Irk ayrımını genel olarak değerlendirecek olursak; yukarda sıralanan üç ŏğe kapsamında insan haklarının çiğnendiği ve ihlal edildiği normal siyasal gelişim ve iç istikrardan yoksun koşulların egemen olduğu baskıcı bir durumu ifade etmektedir.

\section{D - KAVRAM}

Insanlığa karşı suçlar kavramının kapsamına hangi tür suçların girdiği, uluslararasi ceza mahkemeleri statiilerinin incelenmesi ile yanıt bulunabilecek bir sorundur. Nuremberg, Eski Yugoslavya Uluslararası Ceza Mahkemesi (EYUCM), Ruanda Uluslararası Ceza Mahkemesi (RUCM) ve Roma Uluslararası Ceza Mahkemeleri Statüleri, insanlığa karşı suçların kapsamını, birbirlerinden farklı öğeleri içerecek şekilde tanımlamalar yaparak belirlemişlerdir.

Nuremberg Mahkemesinde insanlığa karşı suçlar "savaş süresince veya savaştan önce öldürme. imha, köleleştirme, sürgün ve sivil insanlara karşı girişilen diğer insanlık dışı muameleler veya mahkemenin yargı kapsamına giren suçlarla ilintili dini, siyasi veya urkçı nedenlerden dolayı yargılama" şeklinde tanımlanmıştır ${ }^{27}$. EYUCM ve RUCM Statüleri birbirlerine benzer ögeleri taşıyan tanımlamalar yapmışlardır: Öldürme, imha, köleleştirme, sürgün, hapis, işkence, tecaviuz, siyasi, ırksal ve dini nedenlerden dolayı yargılama ve diğer insanlık dışı muameleler ${ }^{28}$. Bunlara ek olarak, Roma Uluslararası Ceza Mahkemesi Statusü, ırk ayrımı ve insan kaybını da

in SENCER. Muzafer : Belgelerle Insan Haklan, Beta Yayınları. 1988.

${ }^{27}$ PAZARCI. Hüseyin, Ulusiararası Hukuk Dersleri, C. IV, Ankara, Turhan Kitapevi. 2000.s.330.

${ }^{2 *}$ ICTY Statüisi் 5. madde, ICTR Statüsü madde 3. 
insanlığa karşı suçlar içine almıştır. Ayrıca Roma Statüsünde, insanlığa karşı suçlas daha ayruntılı ele alınmıştır².

Yukarda belirtilen eylemlerin insanlı̆̆a karşı suç olabilmesi için bazı koşulların gerçekleşmesi gerekir. EYUCM Statỉsü'ne göre bu koşullar, ulustararası ve ulusal nitelikteki bir silahtı çatışmanın olması ve bu çatışmakr sırasında eylemin sivillere yönelik olmasıdır (mad.5). Bunlara ek olarak, RUCM Statüsü, bir eylemin insanlığa karşı suç oluşturabilmesi koşullarm: siyasal. ulusal, ırksal, etnik ve dini nedenlerden ötürii sistematik ve geniş çaplı olarak sivillere yönelik doğrudan eylemler olarak belirtmektedir ( mad.3 ). Benzer bir şekilde, Roma Statïsünde, insanluğa karşı girişilen suçları oluşturan eylemlerin, sivillere karşı doğrudan yapılması ya da sistematik bir eylem niteliğinde olması gerektiğini belirtmektedir (mad.7).

\section{E- INSANLIĞA KARŞI SUÇLARA ILIŞKIN TEMEL YAKLAŞIM FARKLILIKLARI}

EYUCM ile RUCM Statüleri arasındaki belirgin fark, silahl çatışmaların niteliğine ilişkindir. Nuremberg Statüsünün $6 / \mathrm{c}$ maddesine göre ise, Nurmberg Mahkemesinin insanlığa karşı suçlar kapsamındaki yargı yetkisi. II. Dünya Savaşı öncesi ve savaş sırasında meydana gelen ihlallerle sınırlandırılmıştı. Mahkeme 1939 yılı öncesi, insanlığa karşı suçlarm savaş suçu veya batışa karşı suçlarla ilintili olması koşuluna gerek görmekteydi.

Günümïzde, UCM ve RUCM Statiilerinde de belirtildiği gibi, uluslararası hukuk, insanlığa karşı suçları oluşturan eylemlerin mutlak bir silahlı çatışma durumu olması gereğini göz önünde bulundurmamaktadır ${ }^{30}$. EYUCM Statüsünde insanlığa karşı suçlar doğrudan sivillere karşı girişilen eylem olarak belirtmesine rağmen, eylem ile silahlı çatışma veya eylem ile sivillere karşı saldırı arasında belirsizlikler mevcuttur ${ }^{31}$.

İnsanfığa karşı suçlara ilişkin mahkeme statülerinde görülen ikinci farklılık, RUCM Statüsüntin insanlığa karşı suçlar için bu suçun dini, ırksal, etnik, siyasi ve ulusal temelde sivil halka karşı girişilen sistematik veya

\footnotetext{
"CHESTERMAN, Simon, "An Altogehter Different Order: Defining The Elements of Crimes Aganist Humanity", Duke Joumal of Comparative \& International Lał, Vol. 10. Spring / Summer 2000 s.s. 308. Orneğin tecavüz suçu ICTY ve ICTR'de sade hor şekilde ifade edilmiş iken. Ruma Statüsünde tecavijz suçu seks köleliği, fahişeliğc zorlammi, mecthuri gebelik, zorunlu kısırlış̧ırma ve her tür seks şiddeti şeklinde ayrıntılı bir şckilde bolirtilıniştir.

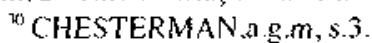

"Ayrıntılar ıçin III. Böliume bakınız.
} 
yaygın saldırı niteliğinde olması gerektiği ifade edilmişken (mad.3), EYUCM Statüsünde bu gibi koşullar ileri sürülmemiştir.

Üçüncü farklılık, insanlığa karşı suç oluşturan eylemlerin RUCM Statüsünde "yaygın ve sistematik olma" durumunun belirsizliğinden kaynaklanmaktadır. Bu iki durumu belirten mahkeme kararlarma rastlamak mümkündür. EYUCM Statïsünde bu ifade bulunmamaktadı. Eylemin "yaygın ve sistematik" olma durumu Roma Statüsünde de belirtilmiştir ${ }^{32}$.

Bu üç farklılığı göz önünde bulundurursak, bir eylemin insanlığa karşı suç oluşturabilmesi için içermesi gereken genel ilkeleri şöyle sıralayabiliriz:

_Yaygın ve sistematik bir saldırı olması,

_Sivillere yönelik olması,

_Siyasi, ulusal, ırksal, etnik veya dini temele dayalı olmast.

\section{F- INSANLIĞA KARŞI SUÇLARIN ORTAK ÖZELIKLERI}

\section{1- Eylemin Silahlı Çatışma Sırasında Meydana Gelmesi}

EYUCM Statüsünde insanlığa karşı suçları oluşturan eylemlerin "çatışma sırasınđa meydana gelmiş olması"nı, suçun oluşabilmesinin bir koşulu olarak belirtmiştir. Nuremberg Mahkemesi de insanlığa karşı suçun oluşabilmesi için, çatışma sırasında meydana gelmiş olmasının yanısıra, suçun savaş suçu ve barışa karşı suç ile bağlantısını aramaktaydı ${ }^{33}$.

RUCM ve Roma Uluslararası Ceza Mahkemesi ise bir eylemin insanlığa karşı suç oluşturabilmesi için mutlak şekilde çatışma sırasında olması koşulunu aramamaktadır.Başka bir dey̧işle, bir eylem, silahlı çatışma sırasında meydana gelmemiş olsa bile, insanlığa karşı suçlar kategorisinde yer alması için diğer özelikleri taşıması yeterli görülmektedir.

\section{2 -Yaygın ve Sistematik Bir Saldırının Parçası Olması}

Sistematik ve yaygın bir saldırının parçaşın oluşturan eylemin ne gibi özellikler taşıması gerektiği konusu oldukça karmaşık bir sorundur. Bu kavramı belirgin bir şekilde tanımlamak, ancak tanımı oluşturan dört öğenin

\footnotetext{
${ }^{32}$ Bkz.Roma Statüsú madde 7.

${ }^{33}$ RATHER-ABRAMS,a.g.e.,s.49.
} 
açıklanmasıyla mümkün olabilecektedir. Bunlar; "yaygın veya sistematik", "saldırı", "politika" ve “ilişki" öğeleridir.

\section{a- Yaygm veya Sistematik}

"Yaygm veya sistematik" terimleri altematif koşulları ifade etmekıedir. "Yaygın" terimi mağdurların sayısını belirtirken, " sistematik" terimi bir politika veya planın varlığına işaret eder ${ }^{34}$. Bu koşulların amacı, insanlığa karşı suçlar ile tesadüfi ve tekil eylemlerin birbirlerinden farklılıklarını belirtmeklir.

Nuremberg Mahkemesi yargılamalarında ve II. Dünya Savaşı sıasıında kurulan BM Savaş Suçları Komisyonunun çalışmalarında, insiunlığa karşı suçun oluşabilmesi için "sistematik geniş çaplı" bir eylemin parçası olma şartı aranmıştır ". RUCM I. Dava Dairesi UHK'nun 1996 tarihli Suç Kavramına İlişkin Kurallar Taslağında, "yaygın" teriminin "çok sayıdaki mağdura karşı doğrudan ve ağır bir şekilde kolektif olarak yapılan geniş çaplı, sık sık tekrarlanan ve geniş kapsamlı eylem" olarak tanımlanabileceğini aktarmaktadır ${ }^{36}$. Benzer şekilde II. Dava Dairesi, "yaygın" teriminin, çok sayıdaki mağdura karşı doğrudan yapılan bir saldırı anlamma geldiğini ifade etmektedir ${ }^{37}$.

Yine aynı şekilde, "sistematik" terimini, UHK, "sürekli kamu ve özel kaynakları kapsayan ortak politikalar temelinde, benzer yöntemlerin takip edilmesi" şeklinue tanımlamaktadır. Bu paralelde, RUCM II. Dava Dairesi Savcısı Kayishema. "sistematik" teriminin, bir plan ve program izlenerek uygulanan eylem olabilecełgini belirtmektedir ${ }^{38}$.

\section{b- Saldırı}

"Saldlrr" teriminin tanmlanmasında EYUCM ile RUCM statüleri arasında fark/1lklar mevcuttur. EYUCM Statïsünde saldırı, silahlı çatışmalarla ilişkilendirilirken, RUCM Statüsünde saldırının bir silahlı çatışma ile ilişkilendirilmesi gerekmemektedir. RUCM Statiisüniin 3. maddesinde saldırının içeriğ ayrıntısıyla belirtilmiştir. RUCM I. Dairesinden Save1 Akeyesu, saldırının, RUCM Statüsünde sıralanan yasadı̧̧ı eylem çeşitleri gibi eylemler olarak tanımlanabileceğini

\footnotetext{
"CIIESTERMANA.g.m.s.315.

15 RATHER-ABRAMS, a.g.e.,s.58.

"th Prosecutor v. Akayesu, No. lCTR-96-4-T.580 8 ( ICTR, Trial Chamber, Sep.2.1998).

${ }^{37}$ No. ICTR-95-1-T.123 ( JCTR. Trial Chamber, May 21.1999).

${ }^{3 *}$ No.ICIR-95-I-T,I23. ( ICTR,Trial Chamber,May 21,1999).
} 
söylemektedir ${ }^{39}$. II. Daireden Savcı Kayishema ise, saldtrının RUCM Statüsünde belirtilen eylemlere benzer eylemler olduğunu belirtir. Roma Statiisü̈nde saldırı bir çok fiilden oluşan eylem şeklinde tanımlanır ${ }^{40}$.

Bu tanımlamalarda dikkat çeken nokta, eylemin, saldırının bir parçası oIması gerekliliğidir. Bununla birlikte, saldırı, yaygın ve sistematik boyutta bir imha eylemi de olabilir. Bu durumda eylem, insanhı̆̆a karşı suç oluşturur. RUCM Statïsünde belirtilen saldırının "yaygın" veya "sistematik" olması, saldırıyı, bir iç hukuk suçu olmaktan çıkarmakta, insanlığa karşı işlenen bir suç haline getirmektedir.

\section{c- Politika Gereği}

Politika gereğinden kast edilen, saldırının "yaygın" veya "sistematik" veya her iki özelliğiyle bir eylem ya da bazı politika biçimleriyle bağlantılı olmasıdır. Politikanın mutlak bir şekilde merkezi yönetimin bir politikası olması gerekmez; bu politika, bir örgüt veya diğer özel grupların politikaları da olabilir ${ }^{41}$. Bu politikanın koşulu, temelde (özelde), insanlığa karşı suç sayılamayacak rastlantısal veya tekil eylem durumlarının tekrarı olmasıdır. Insanlığa karşı suçlar, insanlık vicdanını rencide eden ve uluslararası toplumun müdahalesini haklı kılan suçlardır. Çünkü, bunlar tekil ve bireylerin rastlantı eseri olan eylemleri değil, tersine, sivillere yönelik bilinçli saldırılardır ${ }^{42}$.

\section{d - Bağlantı}

"Saldırının bir parçası olma" ifadesi, yaygın veya sistematik saldırı ile söz konusu eylem arasında bir bałlantıya gereksinim olduğunu göstermektedir. UHK'nun suç kurallarına ilişkin taslağının 18. maddesi, insanlığa karşı suçların "bir hîkkümet, örgüt veya grubun doğrudan yaptığı ya da teşvik ettiği bir eylem"den kaynaklanması gerektiğini belirtir ${ }^{43}$.

Bu nitelikler, EYUCM Mahkemesinde görülen "Tadic Davası"nda ifade edilmiştir ${ }^{44}$. Benzer şekilde, 1945-1955 yılları arasında Almanya'yı işgalleri altında tutan müttefik güçlerden İngiltere'nin denetimi altındaki bölgede

${ }^{39}$ No.ICTR-95-4-T,581. ( ICTR,Trial Chamber,May 2 1,1999).

* Roma Statüsü madde 7 ( 2 ) (a ).

" CHESTERMAN,a.g.m., s.315.

\$2 Tadic No-IT-94-]-T.653. (ICTY,Trial Chamber,May 7,1997).

${ }^{43}$ CESTERMAN,a.g.m.s. 317 .

${ }^{44}$ Prosecutor v. Dusko Tadic, (Opinion And Judgment) No-IT-94-1-T,655. (ICTY, Trial Chamber, May 7.1997). 
görev yapan İngiliz Bölge Yüksek Mahkemesi, bireysel eylemlerin insanlı̆̆a karşı suç oluşturabileceğini belirtmiştir ${ }^{45}$.

Bir suçun insanlığa karşı suç oluşturabilmesi için nedensel bir bağa gereksinim yoktur; eylemin bir devlet veya örgüt ya da grup tarafindan yapılması veya teşvik edilmesi yeterlidir. EYUCM, bir suçun insanliğa karşı suç oluşturabilmesi için iki koşulun gerekliliğini belittir. Bunlardan birincisi. iddja edilen suçların sivillere karşı girişilen saldırnyla ilintilendirilmesidjr. İkinci koşul ise, eylemcinin eyleminin bununla ilintili olduğunu bilmesidir.

\section{3- Sivillere Karşı Doğrudan Bir Eylem Yapılması}

Bir eylemin insanlığa karşı suçlar kategorisine girebilmesi için bu eylemin, sivillere yönelik bir eylem niteliğinde olması gerekmektedir. Gerek Nuremberg Mahkemesi kararlarında gerekse EYUCM ve RUCM Statïlerinde yaygın ve sistematik saldırı eyleminin sivillere karşı bir nitelik taşıması, insanlığa karşı suç oluşturmasının bir koşulu olarak belirtilmektedir.

"Siviller" kavramı kapsamma kimlerin girdiğine ilişkin RUCM II. Dava Dairesi savcısı Kayishema, kamu düzenini koruma görevini yürüten silahlı kuvvetler dışındaki tüm kişilerin bu kavram kapsamına girdiğini söylemektedir ${ }^{\text {th }}$. Siviller kavramı, bir uluslararası insancıl hukuk kavramıdır. Dolayısıyla, bu kavramm içeriğinin ne olduğu sorusunu yanıtlamak için. uluslararası silahlı çatışmalar ve uluslararası olmayan çatışmalarda bu kavramın sınırlarının araştırılması gerekmektedir.

Uluslararası silahlı çatışmalara ilişkin 1977 Cenevre Sözleşmeleri ek 1. Protokolü, "siviller" $i$, silahlı güçlerle herhangi bir ilişkisi bulunmayan kişiler olarak tanımlamaktadı ${ }^{47}$. Bu bağlamda, I. Protokol, polis güçlerinin silahlı güçler kapsamında değerlendirilip değerlendirilmeyeceğine ilişkin tartışmalara neden olmuştur. Çünkü, bazı devletler, polis güçlerini savaş durumlarında silahlı kuvvetler ile birleştirirken, bazı devletler polis gïçleri için bu yönteme başvurmamaktadır.

Uluslararası olmayan silahlı çatışmalara ilişkin Il. Protokol, silahlı kuvvetler kavramından "düzenli silahlı kuvvetlerin" anlaşılması gerektiğgini ifade etmiş: iç düzeni sağlamakla görevli polisleri ve benzeri diğer yasal güçleri bu kapsam dışında tutmuştư ${ }^{4 \bar{x}}$.

\footnotetext{
45 CHESTERMAN a.g.m.s.318.

* Prosecutor v. Kayishema No. ICTR-95-T. 127.( ICTR. May 21, 1999 ).

${ }^{17}$ Cencvre Sözleşmeleri ek protokol madde 50(i).

th CESTERMAN.a.g.m.s.323.
} 
"Silahlı kuvvetler"e ilişkin bu farklı yaklaşımlar birbirlerine karşıt görülebilir. Fakat, bu karşıtlık, yalnızca kavramın farklı amaçlar için kullanılmasından ileri gelmektedir. I. Protokolde, "silahlı kuvvetlere" ilişkin yapılan dar tanım, uluslararası silahlı çatışma durumlarında sivilleri korumaya yöneliktir. II. Protokolde ise, "silahlı kuvvetler" teriminin tanımı, II. Protokolün uygulama kapsamındaki durumlarda uygulanmak için yapılmış bir tanımdır". İnsanlığa karşı suçlar kapsamında "siviller" tanımındaki karmaşıklığı gidermek için yukarda belirttiğimiz iki duruma ek olarak, silahlı çatışmaların bulunmadığı durumu incelemekle kavramı biraz daha belirgin hale getirmek mümkündür.

Uluslararası silahlı çatışma durumlarında "siviller", Cenevre Sözleşmeleri ve ek I. Protokolde, "çatışmaya taraf silahlı kuvvetler üyesi olmayan kişiler" diye tanımlanmıştır. Bu tanım, uluslararası insancıl hukuk çerçevesinde "sivil" tanımına açıklık getirmektedir.

Ek 1I. Protokolde, uluslararası olmayan silahlı çatışma durumlarında, "siviller", "düşman kuvvetlere bağlı olmayan veya katılmayan kişiler" diye tanımlanmaktadır. Dolayısıyla bu kişiler, koruma altında bulunan kişiler sınıfına dahil kimselerdir. Ancak, bu sınıftan sivillere karşı eylem yapan polis ve paramiliter grup üyeleri bu tanım dışında tutulmaktadır ${ }^{51 !}$.

Silahlı çatışmanın bulunmadığı durumlarda "siviller" terimi kapsamına kimlerin girdiği sorusunun yanıtını Cenevre Sözleşmeleri ve Ek Protokollerinde açık bir şekilde bulmak mümkün değildir. Ancak, söz konusu Sözleşmeler ve Ek Protokollerden bazı öngörülerde bulunmak mümkündür. Söz konusu belgelerde tanımlanan uluslararası silahlı çatışma durumları ile uluslararası olmayan silahlı çatışma durumlarında siviller tanımı, insanlığa karşı suçların doğasını bütünleyen önemli öğeleri içerir. Buna paralel olarak, Ek II. Protokol nygulamasımı getirdiy̌i temel garantiler dikkate alınarak uygun bir sivil tanımı yapılabilir. Tüm bunlar göz önüne alındığında, silahlı çatışma olmayan durumlarda, siviller, düşmanca hareketlere katılmayan kişiler olarak tanımlanabilir. Bu tanım kapsamından, sivillere yönelik eylemlere katılan silahlı güç üyeleri hariç tutulur.

\section{4- Ayırımcilı Temelinde Yapılmalı}

Ulusal, siyasal, etnik, ırksal ve dini nedenlerden ötürü suç işlemek insanlığa karşı suçlardan sayılmaktadır. RUCM Statüsünün 3. maddesinde

\footnotetext{
${ }^{49}$ Ibjo .s.324

${ }^{514}$ lbid .5.324.
} 
yapılan bu düzenleme klasik uluslararası hukukun, insanlığa karşı suçlara ilişkin belirttiği koşullara eklemelerde bulunmuştur ${ }^{5 !}$.

\section{G-INSANLIC̆A KARŞI SUÇTÜRLERI}

Insanlığa karşı işlenen suçları tek tek incelemek çalışmamızın sınırlarını aşacağından, burada yalnızca insanlığa karşı suçlardan en çok rastlanan altı türünü inceleyeceğiz. Bunlar, adam öldürme, imha etme, köleleştirme ve zorunlu çalıştırma, sürgün ve tecavüz suçlarıdır.

\section{1- Adam Öldiirme}

Adam öldürme, tüm devletlerin ceza yasalarında tanımlanmış, bilinen bir suç tipidir. Adam öldürme, Nuremberg Şartının 6. maddesi, 10 numaralı Miittefik Devletler Kontrol Yasası'nın 2. maddesi, EYUCM Statüsünün 5. maddesi ve RUCM Statüsünün 3. maddesi ve diğer bir çok uluslararası belgelerde yasaklanmış bir eylemdir.

Adan öldürme eylemi için hangi koşulların gerektiğini RUCM'den savcı Akayesu şöyle belirtmiştir:

- Mağdurun öldürülmesi,

-Öldürme eyleminin sanığın veya emri altındakilerin ihmal veya yasadışı eylemlerinden kaynaklanması.

-Sanığın veya emri altındakilerin, öldïrme eylemlerini isteyerek ve kasti olarak yapması.

Öldürme eylemi, sivillere karşı yaygın ve sistematik bir saldırının parçası olmalıdır. Mağdurun, siyasi, etnik, dini ve ulusal ayırımcılığa dayanan nedenlerden ötürü öldürüilmesi halinde bu eylem insanlığa karşı suçlar kategorisine girer.

Yukarda belirtilen koşullar kesinlik arz etmemekte; bazı muğlaklıklar içermektedir. Her şeyden önce. "emri altındakiler" ifadesinden neyin kastedildiği belirsizdir. RUCM'nin 6. maddesi, bireysel cezaî sorumluluğun ve özel suçlarda ortak sorumluluğa ilişkin bir işbirliğinin gerekli olmadığını belirtmektedir. Mahkeme, sanığın veya emri altındakilerin veya yardımcısının öldüirmek kasdın taşımış olması gerektiğini belirtmekle: asli failin, -taksiren de olsa- öldürme eylemini gerçekleştiren kişi olması

st Jbid .5.328. 
gerektiğini söylemektedir. İkinci muğlaklık, "mağdurun ayırımcılı̆̆a dayalı bir nedenle öldürülmesi” ifadesindedir. Bu ifade, belirsiz bir genel duruma karşılık gelmekte; yoruma açık ve tartışllabilir durumlar yaratmaktadır.

4 Ocak 2000 tarihinde EYUCM'de ele alınan savcı Kupreskic'in iddianamesinde, adam öldürme eyleminin öğeleri şöyle belirtilmiştir: "Bu öğeler, sanığın ihmal veya eylemleri sonucu magdurun ölümüne neden olan olaylardır. Sanık bir kişiyi öldürmek niyetiyle yasadışı bir eylemle kişiyi ağır yaralar veya öldürürse ölümünden dogrudan sorumlu olur"s2.

Bir öldürme eyleminden söz etmek için aşağıdaki öğelerin bulunması gerekir. Bunlar:

-Sanı̆̆ın ihmal veya yasadışı eylemi sonucunda bir kişinin ölümüne sebebiyet vermesi,

-Sanı̆̆ın bir kişiyi öldürmeye niyetlenmesi veya sanığın bir kişiye ağır bir şekilde zarar verme niyetinde olmasi,

-Bu eylem ve ihmalin kasıtlı olması gerekir.

\section{2- İmha etme}

Bu suç türü daha çok Ruanda Uluslararası Ceza Mahkemesinde görülmüştür. RUCM Statüsünün 3/c maddesine göre, imha, insanlığa karşı bir suçtur. İmha, bir grup insana karşı yapılan suç niteliğindeki bir eylemdir. $\mathrm{Bu}$ açıdan imha, adam öldürmeden farklılık gösterir. İmha için geniş ölçekli bir yıkım gerekirken, öldürmede, bir kişinin hayatını kaybetmesi yeterlidir.

RUCM Dava Daireleri kararlarında bu suçun tanımına ilişkin birbirleriyle çelişkili yaklaşımlar mevcuttur. I. Dava Dairesi, imhayı oluşturan ögeleri şöyle belirtmektedir:

-Sanık veya onun emri altındakilerin (veya yardımcılarının) belirli kişilerin ölüm olayına katılmaları,

-Eylem veya ihmalin yasadışı ve kasti olması,

-Yasadıß̧ı eylem veya ihmalin yayğın ve sistematik bir saldırının parçası olması,

${ }^{52}$ Prosecutor v. Kupreskic no. IT-95-16-T (ICTY. Trial Chamber II.2000). 
-Saldırının sivillere yönelik olması,

-Saldırının, ulusal, siyasal, ırksal, etnik veya dinsel temele dayalı ayırımcılığa bağlı olarak gerçekleştirilmesi ${ }^{53}$.

Cherif Bossiouni'ye göre ise, imha, sadece "geniş ölçekli bir öldürme" değildir. Ona göre imha, amaçlı veya amaçsız öldiirmedir. Bunun yanı sıra, sonucunu arzulayan ve bilen bir grup insanın, bir başka grup üyelerini planlı ve bir program çerçevesinde öldürmesidir. ${ }^{5.4}$

RUCUM II. Dava Dairesi Savcısı Kayishema, jddianamesinde, imhanın öğelerini şöyle sıralamıştır:

-Sanığın, bir çok kimsenin öldürme eylemine veya bir çok kimsenin öldurülmesine neden olacak şartların oluşumuna katılması.

-Sanığın eylem ve ihmalinde öldürme amacı taşıması veya büyük unursamazlık ve ihmalin bu ölümlere neden olması,

-Sanığın eylem veya ihmali geniş çaplı katliamların k. parçası olması,

-Sanığın eylem veya ihmalinin sivillere yönelik ılusal, siyasi, etnik, ırksal veya dini nedenlere dayanan yaygın ve sistematik saldırının bir parçası oluşturmast. ${ }^{5.5}$

Yukarıda tanımlanan öğelerden hareketle "imha" suçunu şu şekilde tanımlayabiliriz: İmha; sanığı, -vurdumduymazlık ve büyük bir umursamazhıkla- eylem ve ihmallerinin bir çok kişinin ölümüne doğgrudan katkısının bulunduğu (bu katkı sadece ölüme neden olmak için değil, aynı zamanda ölüme sebebiyet veren yaşam koşullarm yaratılmasını da içerir) bir çok kişinin ölümüne neden olma amacını taşıyan bir suçıır.

\section{3- Tecavüz}

Tecavï. ve cinsel şiddet suçları, uluslararası ceza hukukunun en çok tartışmalı suçlarındandır. RUCM I. Dava Dairesi, tecavüzü, "bir insana yapılan zorla fiziksel cinsel müdahale" 5 diye tanımJar. II. Daire, tecavïzü,

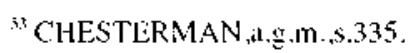

it Ibid .5.335.

"Prosecutor v. Akcyesu, no.lCTR $96-4$ T. $591-592$ (ICTR Trial Chamber. September 2. 1998)

"ASKIN. Kelly D., "Sexual Violation in Decisions and Indictments of The Yugoslavia and Rwanda Tribunals: Current Status". AJll , Vol.93, No. 1999, s. 106 
saldırının bir biçimi olarak belirtmektedir. 1984 tarihli "İşkence ve Diğer Insanlık Dışı ve Aşağılayıcı Davranış veya Cezalara Karşı Sözleşme", işkenceyi tanımlayacak özel eylem kataloğunu belirtmeden, devletin yaptırım kavramı üzerinde durmuştur.

EYUCM, tecavüzü, savaş hukuku ve teamüllerinin ihlali olarak görmektedir. Tecavüzün öğeleri olarak şunları belirtmektedir: Cinsel birleşme ve mağdura karşı baskı, zorlama veya tehdit. Bunlara ek olarak, tecavïz ile sivillere karşı yaygın ve sistematik saldırı arasında bir bağlantının bulunması öğesini de saymak gerekir ${ }^{57}$.

Roma Uluslararası Ceza Mahkemesi Statüsünde cinsel şiddet suçları 7 ve 8. maddelerde belirtilmiştir. Statü, cinsel şiddet suçlarmı şu şekilde sıralamıştır: Tecavïz, seks köleliği, fahişeliğe zorlama, zorunlu gebelik, zorunlu kısırlaştırma ve Cenevre Sözleşmelerinin ağır ihlalini oluşturan savaş suçları veya insanlığa karşı suçlar kapsamına giren cinsel şiddetin her türüi $^{\text {s. }}$. Statï, cinsel suçları hem uluslararası hem de ulusal çatışmalarda işlenen savaş suçları kapsamında ele almıştır. Buna ek olarak insanlığa karşı suçlar içinde de cinsel suçları saymıştır ${ }^{54}$.

\section{4- Köleleştirme ve Zorla Çalıştırma}

Köleleştirme insanın temel haklarından yoksun bırakılmasıdır. Zorla çalıştırılma ise, kişilerin kendi bedenleri üzerindeki kontrolünden yoksun bırakılması, emeğinin karşılığının verilmemesidir. Köleleştirme ve zorla çalıştırılma, Nuremberg, Eski Yugoslavya, Ruanda ve Roma Uluslararası Ceza Mahkemelerinde, insanlığa karşı suçlar bağlamında ele alınmıştır.

\section{5- Sürgiin}

Sürgün, insanların kendi ülkelerinden diğer bir ïlkeye zorla göç ettirilmeleridir. Sürgün. Nuremberg, Eski Yugoslavya ve Ruanda Uluslararası Ceza Mahkemelerinde suç olarak kabul edilmiştir.

Nüfusun ülke içinde bir yerden başka bir yere zorunlu transferinin, sürgün kapsamında ele alınıp alınamayacağı hususu tartışnıalıdır. Bu konu henüz uluslararası bir davaya konu olmamıştır. Ayrıca, konu Nuremberg, Eski Yugoslavya ve Ruanda Uluslararası Mahkemeleri Statülerinde ele

${ }^{57}$ Ayırıntulı bilggi için bkz. Askin. sexual.., s. $100-105$.

${ }^{58}$ BENDONT, Barbara - MARTINEZ, Katherine Hall, "Ending Impunity for Gender Crimes Under The International Criminal Court". The Brown Journal of Worid Affair,Vol.VI,No. 1.1999.s.71.

${ }^{59}$ Ibid. 8.71 . 
alınmamışır. Bu gibi durumlarda suç, sürgünün kendisinden değil, devletlerin amaçları ve kullandığı yöntemlerden oluşmaktadır ${ }^{\text {(x) }}$. Dolayısıyla, devletler suç oluşmaması için bu durumun gerektiği şartlar oluşunca, insancıl yöntemlere başvurmakla insanlığa kaş̧ı suç işleme durumuyla karşı karşıya kalmanaktadırlar.

\section{SONUÇ}

İnsanlığa karşı suçlar kavramı, sınırları henuiz tam olarak çizilmemiş, gelişmekte olan bir kavramdır. Ilk olarak 1907 La Haye Sözleşmelerinde geçen bu kavram, I. Dünya Savaşı sonrasında savaş suçları çerçevesinde ele alınmış ve II. Dünya Savaşı sonrası kabul edilen Nuremberg Satüsü ile uluslararası hukukta ilk defa bağımsız bir suç türü olarak yer almış ve bireylere karşıı ileri sürülmüştür.

İnsanlığa karşı suçlar, günümüzde faaliyetlerini sürdüren EYUCM, RUCM ve UCM Statülerinde ayrı bir suç türü olarak yer almaktadır. İnsanlığa karşı suçlar bir çok uluslararası metinde farklı tanımlanmakla birlikte, bu tanımlamaların ortak yönü; insanlığa karşı suç oluşturan eylemlerin, ister kendi ulusundan isterse farklı uluslardan olan insanlara karşı barış veya savaş zamanında işlenen özel eylem türleri olması ve insanların ulus, etnik grup, dini inanç ve rrki nedenlerden ötürü yargilanmalarıdır.

İnsanlığa karşı suçlarla ilgili hukuksal düzenlemeler de gelişme aşamasındadır. İnsan haklarına ilişkin uluslararası kamuoyu ilgisi ile bu hakların korunmasına ilişkin çabalar ve özellikle uluslararası ceza mahkemelerinin almış olduğu kararlar, bu gelişmeye katkı sağlamaktadır. Ögretide insanlığa karşı suçların, "ihlal oluşturma", "ayıımcı amaçlara dayanma" ve "yaygın olma" nitelikleri, bunları adli suçlardan ayıran özellikler olarak değerlendirilmektedir ${ }^{6 !}$.

Insanlığa karşı suçlar ile savaş suçları arasında belirgin bir ayrım yapmak oldukça güçtiir. Her iki gruba giren suçlarm nitelikleri bir çok durumda örtüşmekıedir. Buna karşın, suçların oluşum koşulları, bu ayrımda yardume bir unsur olarak ele alınabilir. Bu durumda da, uluslararası ceza mahkemeleri statülerinde insanlığa karşı suçların cezalandırılma koşullarına ilişkin uygulama koşulları ile anılan suçun işlenmesini yasaklayan fiillerin listesi ve niteliklerine iljşkin ayımlar ortaya çıkmaktadır ${ }^{62}$.

"NATHER-ABRAMS,a.g.e.s. 69.

${ }^{\circ}$ PAZARCI. C.IV, $\$ 332$.

6.? Nuremberg Uluslararası Ceza Mahkemesi insanlığa karşı suçları savạ ve savaş öncesi durumda savaşla ilintili durumlarla smarlarken, Eski Yugoslavya Ulluslararası Ceza 
Nuremberg, EYUCM, RUCM, UCM Statüleri ve UHK'nun çalışmaları, insanlığa karşı suçlara ilişkin parametreler belirlemelerine rağmen, bu suçun tanım ve kapsamına açıklık kazandırma konusunda yetersiz olduklarm söylemek gerekir. Başka bir deyişle, ulusłararası hukuk, henüz kişilerin bu suçu işlemelerinden dolayı yargılanmaları ve cezalandırılmalarına ilişkin tüm soruları açık ve tan olarak yanıtlayacak düzeyde yeterli argümanlara sahip değildir. Ancak, uluslararası hukukta yavaş da olsa bu tür düzenlemelere gidilmektedir. Günümüzde insanlığa karşı suçlar, kişilerin cezaî sorumluluğa sahip olduğu ve bu konuda evrensel yargılamaya gidildiłi bir uluslararası suç olarak kabul edilmektedir. Bu konuda yapılması gereken, insanlı̆̆a karşı suçun tanımı üzerinde konsensüsün săglanmasıdır. Bu kapsamda, uluslararası ceza mahkemeleri, uluslararası ceza hukukunun gelişmesi yönünde hayati bir öneme sahiptirler.

Özet olarak belirtmek gerekirse; insanhl̆ga karşı suçlar kavramı, gerek ulusal hukuklarda gerekse uluslararası hukukta yerleşmiş bir kavramdır. Devletker bu suçu işleyen kişileri uluslararası ceza mahkemelerinde yargılama konusunda giderek artan bir şekilde işbirliğine gitmektedirler.

\footnotetext{
Mahkemesi anılan suçun silahlı çatışma durumunda işlenmesi durumda yargıłanmayı kabul etmekte, Ruanda Uluslararası Ceza Mahkemesi sivillere yönelik saldırı ile bağlantulı bu suçun işlenebileceğini belirtmekte. Roma Uluslararası Ceza Mahkemesi Statüsü ise bu suçun oluşabilmesi için silahlı çatışma koşulu aramamaktadır.

İnsanlı̌̆a karşı suçların kapsamında olan eylemlerin listesinin ve nitelikJerinin farklılıkları da söz konusudur. Nuremberg Mahkemesi Statüsünde ırza geçme rìli cezalandırma kapsamında değılken, Eki Yugoslavya ile Ruanda Malıkemeleri Statülerinde bu tiil cezalandırma kapsamında ele alınan suçtar içinde sayılmış. Roma Mahkemnesi Statüsü ise ırza geçme fiili yanında birçok cinsel fỉili cezalandırma kapsamına almıştır.
} 


\section{KAYNAKÇA}

\section{KITAP VE MAKALELER}

Askin , Kelly D.: "Sexual Violation in Decisions and Indictments of Yugoslavia and Rwanda Tribunals: Current Status", AJIL, Vol. 93, No.1, 1999, s.97- 123 .

Askin, Kelly Dawn: War Crimes Aganist Women, The Hague, Martinus Nijhoff Publishers, 1997.

Beigbeder, Yves: Judging War Criminals, London, Macmilan Press and St. Martin Press, 1999.

Bendont. Barbara, Katherine Hall Martinez,

"Ending Impunity for Gender Crimes Under The International Criminal Court", The Brown Journal of World Affair,Vol.VI,No. 1,1999. ( çevirimci ) www.brown.edu /students/ journal of world affairs/ index html. 27.09.2000.

Chesterman, Simon: "An Altogehter Different Order : Defining The Elements of Crimes Aganist Humanity", Duke Journal of Comparative \& International Law, Vol. 10, No.2, Spring/Summer 2000, s.307-320.

Clark, Roger S.: "Crimes Aganist Humanity at Nuremberg", Nuremberg Trial and International Law, Ed. George Ginsburgs, W.N. Kudriavtsev, Dordrecht, Martinus Nijhoff Publishers, 1990, S.177 - 211.

Clark, Roger S.: "Crimes Aganist Humanity at Nuremberg", Nuremberg Trial and International Law, Ed. George Ginsburgs, W.N. Kudriavtsev , Dordrecht, Martinus Nijhoff Publishers , 1990, S.177 - 211.

Cotler, Irwin : "Regina v. Finta ( 1994 ) 1 s.c.r. 701. Supreme Court of Canada", March 24,1994, AJIL, Vol.90,No.3,1996, s.461 - 477.

Draper,G.I.A.D.: "The Modern Pattern of War Criminality", War Crimes in International Law, Ed. Yoram Dinstein - Mala Tabory, The Hague, Martinus Nijhoff Publishers,1996, s.141 - 183.

Greenspan, Moris: The Modern Law of Land Warfare. California. University of Califomia Press, 1959. -251 .

Lepper, Steven : Remarks, ASIL Proccedings, 7 Nisan 1994, s.245

Pazarcı, Hüseyin: Uluslararası Hukuk Dersleri, C. IV, Ankara, Turhan Kitabevi, 2000.

Rather. Steven R, Jason , Abrahams: Accountability For Human Rights, Atrocities in International Law , Oxford, Clarendon Press, 1997. 
Reshetov.Iu.A.: "International Law and Crimes against The Laws and Costums of War", Nuremberg Trial and İnternational Law, Ed. George Ginsburgs and V. N. Kupriavtsev, Dordrecht, Martinus Nijhoff Publishers, 1990, s.167- 176.

Roberge, Marie-Claude: Jurisdiction of ad hoc Tribunals for The Former Yugoslavia and Rwanda Over Crimes Against Humanity and Genocide", IRRC, No.321,1 November 1997,s.651 - 664 .

Sencer, Muzafer : Belgelerle İnsan Hakları, Istanbul, Beta Yayınları, 1988.

Shaw, M.N.: "Genocide and International Law", International Law at A Time of Perplexity Essays in Honour of Shabtai Rosenne , Ed. Yoram Dinstein , Dordrecht, Martinus Nijhoff Publishers , 1989, s.797 - 820.

Wagner, J. Martin : "Prosecution of War Criminals", Virginia Journal of International Law, Vol.29,1989, s. 903 - 936.

Wyngaert, Christine Van Den,

Guy, Stessens: International Criminal Law, The Hague, Kluwer Law International,1996

\section{BELGELER}

No. ICTR-95-1-T,123 ( ICTR, Trial Chamber, May 21,1999).

No.ICTR-95-1-T,123. ( ICTR, Trial Chamber,May 21,1999).

No.ICTR-95-4-T,581. ( ICTR,Trial Chamber,May 21,1999).

Prosecutor v. Akayesu, No. ICTR-96-4-T,580 8 ( ICTR, Trial Chamber, Sep.2,1998).

Prosecutor v. Akeyesu, No.ICTR- 96 - 4- T.591-592 ( ICTR Trial Chamber,September 2,1998).

Prosecutor v. Kayishema No. ICTR-95-T. 127.( ICTR, May 21, 1999).

Prosecutor v. Kupreskic No. IT-95-16-T (ICTY, Trial Chamber II,2000).

Tadic No-IT-94-1-T,653.( ICTY,Trial Chamber,May 7,1997). 